\title{
Pengembangan Formula Hidrogel Balutan Luka Menggunakan Kombinasi Polimer Galaktomanan dan PVP
}

\author{
Dewi Wuragil Rahayuningdyah, Diana Lyrawati, Ferri Widodo, Oktavia Eka Puspita* \\ Jurusan Farmasi, Fakultas Kedokteran, Universitas Brawijaya, Malang, Indonesia
}

INFO ARTIKEL

Sejarah artikel:

Penerimaan

naskah: 12 Juli

2019

Penerimaan

naskah revisi: 14

Mei 2020

Disetujui untuk

dipublikasikan: 02

Juni 2020

\section{Kata kunci :}

Hidrogel,

galaktomanan,

PVP( Polivinil

Pirolidon), rasio

swelling, fraksi

gel

\section{A B S T R A K}

Luka merupakan keadaan dimana fungsi normal dari anatomi kulit mengalami gangguan. Keadaan kulit yang terluka dapat menyebabkan beberapa komplikasi serius antara lain infeksi bakteri, timbulnya eksudat, ataupun terbentuknya bekas luka, oleh karena itu diperlukan penanganan pada luka yang sesuai . Salah satu metode penanganan luka adalah dengan balutan luka, namun penggunaan balutan luka konvensional seperti kain atau kasa mempunyai kendala pada pengaplikasiannya. Hidrogel merupakan suatu jaringan polimer dengan cross link sehingga mempunyai sifat tidak larut air namun dapat menyerap cairan biologis dengan baik. Hidrogel dapat terbentuk dari berbagai macam polimer alami, sintesis, maupun kombinasi antara kedua jenis polimer. Kombinasi dari kedua polimer bertujuan untuk meningkatkan viskositas dari hidrogel dan untuk menghasilkan hidrogel dengan sifat fisik yang lentur, transparan, dan lembut. Tujuan dari penelitian ini adalah untuk mengetahui kombinasi polimer galaktomanan dan PVP yang optimal, berdasarkan karekteristik fisik sediaan, serta hasil uji evaluasi rasio swelling, dan fraksi gel. Kombinasi polimer galaktomanan dan PVP yang digunakan adalah 1:0,5; $1: 1$; dan 1:2. Hasil penelitian menunjukkan bahwa kombinasi polimer galaktomanan dan PVP yang optimal adalah 1:1 dimana menghasilkan karakteristik fisik yang baik, serta hasil uji evaluasi rasio swelling, dan fraksi gel yang baik, dibandingkan dengan penggunaan polimer tunggal pada sediaan hidrogel.

\section{Development of Wound Hydrogel Dressing Formula Using a Combination of Galactomannan and PVP Polymers.}

Keywords:

Hydrogel,

galaktomanan,

PVP (Polivinil

Pirolidon),

swelling ratio, gel

fraction

\section{A B S T R A C T}

Wounds are a condition where the normal function of the skin's anatomy is impaired. The condition of the injured skin can cause several serious complications including bacterial infection, the appearance of exudates, or the formation of scars, therefore it is necessary to deal with appropriate injuries. One method of handling wounds is wound dressing, but the use of conventional wound dressing such as cloth or gauze has problems with its application. Hydrogel is a polymer network with cross links so that it has properties not soluble in water but can absorb biological fluids well. Hydrogels can be formed from various kinds of natural polymers, syntheses, or combinations of both types of polymers. The combination of the two polymers aims to increase the viscosity of the hydrogels and to produce hydrogels with flexible, transparent and soft physical properties. The purpose of this study was to determine the optimal combination of galactomannan and PVP polymers, based on the physical characteristics of the preparation, as well as the results of the swelling ratio evaluation test, and gel fraction. The combination of galactomannan polymer and PVP used is $1: 0.5 ; 1: 1$; and $1: 2$. The results showed that the optimal combination of galactomannan and PVP polymers was 1: 1 which produced good physical characteristics, as well as good swelling ratio and gel fraction evaluation results, compared with the use of single polymers on hydrogel preparations. 


\section{Pendahuluan}

Luka merupakan keadaan dimana fungsi normal dari anatomi kulit mengalami gangguan atau terjadinya kerusakan pada jaringan tubuh terutama pada kulit ${ }^{1}$. Keadaan kulit yang terluka dapat menyebabkan beberapa komplikasi serius antara lain infeksi bakteri, timbulnya eksudat, ataupun terbentuknya bekas luka. Oleh karena itu diperlukan penanganan pada luka yang sesuai untuk meminimalkan adanya komplikasi lainnya.

Salah satu metode penanganan luka adalah dengan balutan luka, namun penggunaan balutan luka konvensional seperti kain atau kasa mempunyai kendala pada pengaplikasiannya. Pembalut luka pada jaman modern sudah sangat berkembang, dimana saat ini balutan luka dibuat untuk memudahkan penggunaannya dan mempercepat penyembuhan luka, salah satu contoh balutan luka modern adalah hidrogel.

Hidrogel merupakan suatu jaringan polimer dengan ikatan silang atau cross link sehingga mempunyai sifat tidak larut air namun dapat menyerap cairan biologis dengan baik.. Hidrogel mempunyai sifat melembabkan permukaan kulit, menyerap cairan biologis maupun eksudat, menjaga permukaan kulit tetap bersih dan menghindarkan kulit dari paparan luar ${ }^{2}$. Hidrogel mampu mengikat cairan dengan baik dikarena adanya ikatan silang, menyebabkan hidrogel dapat menyerap eksudat dari luka ${ }^{3}$.

Hidrogel balutan luka dapat diformulasikan dengan berbagai macam polimer, salah satu polimer yang banyak dikembangkan dalam formulasi pembuatan hidrogel adalah polimer alami. Penggunaan polimer alami lebih disukai karena memiliki biokompatibilitas yang tinggi, tidak toksik, mempunyai kelarutan dalam air yang baik serta kemampuan mengembang yang tinggi ${ }^{4}$. Salah satu polimer alam yang dapat digunakan adalah galaktomanan. Umumnya terdapat empat tanaman yang menghasilkan galaktomanan, yaitu locust bean (Ceratonia siliqua), guar (Cyamopsis tetragonoloba), tara (Caesalpinia spinosa Kuntze), and fenugreek (Trigonella foenum-graecum L.), namun yang paling banyak digunakan adalah galaktomanan yang berasal dari locust bean dan guar gum 5 .

Galaktomanan dari guar gum mempunyai kemampuan dalam menyerap air dalam jumlah besar, stabil pada rentang $\mathrm{pH}$ yang cukup luas, kemampuan mengembangnya yang tinggi dan hanya dapat larut dalam air, mempunyai sifat yang dapat larut air dengan baik, namun kemampuan membentuk gelnya buruk, sehingga dapat mempengaruhi karakteristik sediaan ${ }^{6}$. Selain itu galaktomanan mempunyai kekurangan pada sifat hidrasi yang tidak terkontrol, dan viskositasnya yang tidak stabil ${ }^{7}$.
Penggunaan polimer alam tunggal pada sediaan hidrogel kurang diminati, dimana dinilai masih belum cukup untuk menghasilkan sediaan yang lebih awet, lebih stabil, dan lebih kuat seperti sediaan dari polimer sintetik ${ }^{8}$. Campuran berbagai polimer alami atau sintetik dapat saling memperbaiki kekurangan karakteristik fisikokimia masingmasing dan dapat menghasilkan karakteristik baru pada campuran.

Dalam penelitian ini dibuat hidrogel dengan kombinasi polimer galaktomanan dari guar gum dan PVP. PVP mempunyai struktur yang dapat berinteraksi dengan ikatan hidrogen sehingga dapat mengikat senyawa yang tidak larut dan menjadikannya mudah larut, serta mempunyai sifat higroskopis sehingga dapat mudah menyerap air, membentuk gel yang baik, dan memiliki daya rekat yang tinggi ${ }^{9}$. Kemampuan mengembang PVP dapat meningkat bersama penggunaan polimer alam, dan pada formulasi hidrogel berbasis PVP dapat dihasilkan sediaan yang mudah diaplikasikan, mudah dikontrol, transparan, serta fleksibel ${ }^{10}$. Kombinasi dari kedua polimer bertujuan untuk meningkatkan viskositas dari hidrogel dan untuk menghasilkan hidrogel dengan sifat fisik yang lentur, transparan, dan lembut.

\section{Metode \\ Bahan}

Bahan yang digunakan pada penelitian ini adalah polimer galaktomanan yang berasal dari guar gum, polimer PVP K30 (Polivinilpirolidon) (DJ Labwere), agar (DJ Labwere), PEG 400 (Polientilenglikol) (PT. Croda Indonesia), gliserin (PT. BRATACO), akuades, plastic wrap, kasa, perkamen, dan alumunium foil.

\section{Alat}

Peralatan yang digunakan pada penelitian ini adalah timbangan digital (Mettler Toledo), kulkas, oven (Binder), beaker glass (Duran), gelas ukur, pipet ukur, cawan petri, magnetic stirrer (Arec Velp Scientific), hotplate (IKA ${ }^{\circledR}$ CMAG HS), indikator $\mathrm{pH}$, erlenmeyer, pipet tetes, dan batang pengaduk.

Formulasi Hidrogel Balutan Luka Tabel 1. Komposisi Formula Hidrogel

\begin{tabular}{lccccc}
\hline \multirow{2}{*}{$\begin{array}{c}\text { Nama } \\
\text { Bahan }\end{array}$} & \multicolumn{5}{c}{ Konsentrasi } \\
\cline { 2 - 6 } & F1 & F2 & F3 & F4 & F5 \\
\hline Guar gum & $1 \%$ & $1 \%$ & $1 \%$ & - & $1 \%$ \\
\hline PVP & $0,5 \%$ & $1 \%$ & $2 \%$ & $1 \%$ & - \\
\hline PEG & $2 \%$ & $2 \%$ & $2 \%$ & $2 \%$ & $2 \%$ \\
\hline Gliserin & $1 \%$ & $1 \%$ & $1 \%$ & $1 \%$ & $1 \%$ \\
\hline Agar & $1 \%$ & $1 \%$ & $1 \%$ & $1 \%$ & $1 \%$ \\
\hline Akuades & q.s & q.s & q.s & q.s & q.s \\
\hline
\end{tabular}


Formula hidrogel balutan luka dibuat dengan kombinasi polimer galaktomanan dan PVP, agar ditambahkan sebagai gelling agent, PEG 2\% dan gliserin $1 \%$ pada sediaan digunakan sebagai plasticizer.

Pembuatan hidrogel diawali dengan melarutkan PVP pada pelarut yang sesuai kemudian menambahkan galaktomanan secara perlahan sambil diaduk dengan magnetic stirrer kecepatan $300 \mathrm{rpm}$ selama 30 menit, kemudian ditambahkan agar yang sebelumnya telah dilarutkan dalam pelarut yang sesuai. Ditambahkan PEG $2 \%$ dan gliserin $1 \%$ sambil terus diaduk kecepatan $300 \mathrm{rpm}$ selama 30 menit. Akuades ditambahkan hinggal volume mencapai $100 \mathrm{~mL}$. Selama proses pengadukan suhu dipertahankan pada $40^{\circ} \mathrm{C}$.

\section{Proses Freeze-thaw Hidogel Balutan Luka}

Penggunaan metode freeze-thaw dapat dimanfaatkan untuk menginduksi ikatan silang antar polimer. Ikatan silang dapat terbentuk akibat adanya perubahan suhu ekstrim yang dipaparkan pada polimer. Metode freeze-thaw merupakan salah satu metode dalam membentuk ikatan silang secara fisika.

Sediaan yang telah dicetak dalam cawan petri dibekukan pada suhu $-20{ }^{\circ} \mathrm{C}$ selama 18 jam, kemudian diletakkan pada suhu ruang selama 6 jam. Perlakuan tersebut dilakukan sebanyak 4 siklus, kemudian sediaan dioven pada suhu $40^{\circ} \mathrm{C}$ selama 15 menit.

\section{Evaluasi Sediaan}

1. Organoleptis

Dengan mengamati secara visual warna, dan tekstur serta mencium bau sediaan hidrogel

2. $\mathrm{pH}$

$\mathrm{pH}$ diukur dengan menggunakan $\mathrm{pH}$ indikator, kemudian dilihat pada rentang yang tersedia pada alat.

3. Karakteristik Fisik

Uji evaluasi karakteristik fisik sediaan meiputi diameter, ketebalan, dan daya lipat sediaan. Diameter sediaan diukur dengan menggunakan penggaris, uji ketebalan dilakukan dengan mengukur ketebalan hidrogel menggunakan mikrometer sekrup, uji daya tahan lipatan dilakukan dengan melipat hidrogel berulang kali secara manual pada tempat yang sama sampai putus, kemudian dihitung berapa kali hidrogel dapat dilipat tanpa putus

4. Rasio Swelling

Dilakukan dengan menimbang berat hidrogel utuh sebagai (Wd). Hidrogel yang telah ditimbang ditetesi dengan akuades sebanyak $8 \mathrm{~mL}$ dan ditimbang beratnya pada 5 menit pertama, 15 menit, 25 menit, 35 menit, 45 menit, 55 menit, dan 60 menit sebagai (Ws). Perhitungan rasio swelling menggunakan rumus berikut

11.

$$
\text { Rasio Swelling }=\frac{W s-W d}{W d} \times 100
$$

\section{Fraksi Gel}

Dilakukan dengan memotong hidrogel seberat 3 gram sebagai (W0), kemudian dibungkus dengan kain kasa dan direndam dalam $20 \mathrm{~mL}$ akuades selama 24 jam, lalu dikeringkan kembali dalam oven pada suhu $50^{\circ} \mathrm{C}$, kurang lebih selama 4 jam dan ditimbang beratnya sebagai (W1). Perhitungan fraksi gel menggunakan rumus berikut ${ }^{11}$.

$\%$ Fraksi gel $=\frac{W 1}{W 0} \times 100 \%$

\section{Hasil dan Diskusi}

\section{Organoleptis}

Hasil yang didapatkan yaitu formula 1, 2, 3 dan 5 menggunakan kombinasi polimer galaktomanan dan PVP menghasilkan karakteristik organoleptik yang telah sesuai dengan spesifikasi, namun sediaan hidrogel pada formula 4 menghasilkan karakterisitik organoleptik yang tidak sesuai spesifikasi dimana tekstur hidrogel terlalu fleksibel sehingga sediaan menjadi mudah robek.

Tabel 2. Hasil Uji Organoleptik

\begin{tabular}{cccc}
\hline Formula & Bau & Warna & Tekstur \\
\hline F1 & $\begin{array}{c}\text { Tidak } \\
\text { berbau }\end{array}$ & Transparan & $\begin{array}{c}\text { Lembut dan } \\
\text { fleksibel }\end{array}$ \\
\hline F2 & $\begin{array}{c}\text { Tidak } \\
\text { berbau }\end{array}$ & Transparan & $\begin{array}{c}\text { Lembut dan } \\
\text { fleksibel }\end{array}$ \\
\hline F3 & $\begin{array}{c}\text { Tidak } \\
\text { berbau }\end{array}$ & $\begin{array}{c}\text { Transparan } \\
\text { sedikit } \\
\text { keputihan }\end{array}$ & $\begin{array}{c}\text { Lembut dan } \\
\text { fleksibel }\end{array}$ \\
\hline F4 & $\begin{array}{c}\text { Tidak } \\
\text { berbau }\end{array}$ & Transparan & $\begin{array}{c}\text { Lembut, terlalu } \\
\text { fleksibel, rapuh }\end{array}$ \\
\hline F5 & $\begin{array}{c}\text { Tidak } \\
\text { berbau }\end{array}$ & Transparan & $\begin{array}{c}\text { Lembut dan } \\
\text { fleksibel }\end{array}$ \\
\hline
\end{tabular}

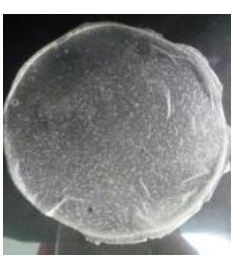

F1

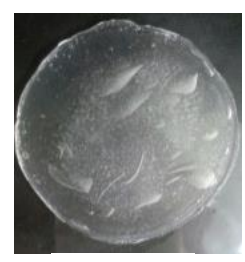

F2

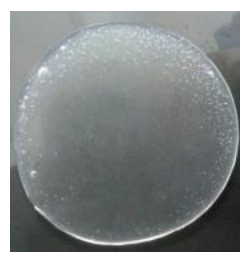

F3

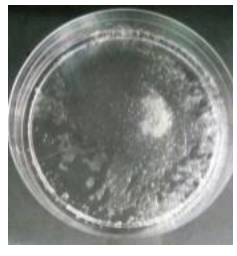

F4

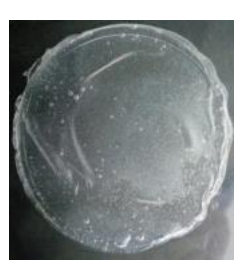


Berdasarkan hasil pada tabel 2 menunjukkan sediaan pada setiap formula mempunyai warna yang transparan, tidak berbau. Namun pada formula 4 tidak memenuhi spesifikasi yaitu tekstur sediaan terlalu fleksibel dibandingkan dengan fromula lainnya. PVP mempunyai karakteristik yang sangat higroskopis sehingga sediaan menjadi lengket dan basah karena menyerap kelembapan dari lingkungan, keadaan tersebut membuat sediaan menjadi terlalu lembek dan rapuh ${ }^{12}$.

\section{2. $\mathbf{p H}$}

Hasil yang didapatkan yaitu $\mathrm{pH}$ sediaan formula 1 , 2, 3, 4 dan 5 telah memenuhi spesifikasi rentang $\mathrm{pH}$ kulit yaitu 4-6, dimana $\mathrm{pH}$ dari masing-masing formula secara berurutan yaitu $5,6,6,5$, dan 6 .

Berdasarkan nilai $\mathrm{pH}$ pada tabel 3 dikatakan bahwa semua formula sudah sesuai dengan spesifikasi dimana. Nilai pH hidrogel yang dihasilkan tidak terlalu asam karena rentang $\mathrm{pH}$ dari polimer yang digunakan yaitu PVP dan galaktomanan yang cukup besar

Tabel 3. Hasil Uji pH

\begin{tabular}{|c|c|c|}
\hline Formula & Hasil & Spe \\
\hline F1 & 5 & pH kulit $4-6^{13}$. \\
\hline F2 & 6 & \\
\hline F3 & 6 & \\
\hline F4 & 5 & \\
\hline F5 & 6 & \\
\hline
\end{tabular}

\section{Karakteristik Fisik}

Hasil pembuatan hidrogel formula 1, 2, 3, 4 dan 5 diuji kesesuaian karakteristik fisik sediaan dan dibandingkan dengan spesifikasi, hasil pengujian karakteristik fisik sediaan hidrogel yaitu berupa diameter, ketebalan, dan daya lipat ditunjukkan pada tabel 4 .

Hasil yang didapatkan yaitu karakteristik fisik sediaan formula 1,2,3, dan 5 memiliki daya lipat yang sesuai dengan spesifikasi yaitu lebih dari 200 kali, namun pada formula 4 didapatkan daya tipat sediaan hanya 5 kali sehingga tidak sesuai dengan spesifikasi. Berdasarkan hasil pengukuran ketebalan sediaan didapatkan formula 3 telah sesuai dengan spesifikasi yaitu sebesar 0,4-0,7 mm, sedangkan formula 1,2,4,dan 5 memiliki ketebalan yang terlalu tipis sehingga tidak mencapai spesifikasi.

Hasil uji karakteristik fisik sediaan yang dilakukan yaitu diameter, ketebalan, dan daya lipat sediaan. Berdasarkan tabel 4 uji ketebalan hidrogel menunjukkan bahwa formula 3 telah sesuai dengan spesifikasi yaitu 0,4 $0,7 \mathrm{~mm}$, namun formula $1,2,4$, dan 5 memiliki ketebalan yang sangat rendah. Ketebalan menjadi salah satu peran penting dalam acceptability sediaan, dimana sediaan yang lebih tipis akan lebih menarik, mempermudah dalam penggunaannya ${ }^{14}$. Ketebalan sediaan berpengaruh terhadap jumlah polimer yang digunakan, pada formula 3 digunakan kombinasi polimer dengan komposisi terbanyak yaitu galaktomanan 1\% dan PVP 2\% 15 . Namun pada formula 1 didapatkan tebal sediaan lebih tinggi dibandingkan dengan formula 2, hal tersebut dapat berkaitan dengan ketepatan penuangan sediaan pada cetakan yang tidak rata, sehingga menyebabkan tebal dari sediaan juga tidak merata.

Tabel 4. Hasil Uji Karakteristik Sediaan

\begin{tabular}{|c|c|c|}
\hline Formula & Hasil & Spesifikasi \\
\hline F1 & $\begin{array}{l}\text { - Diameter : } 8,5 \mathrm{~cm} \pm 0,3 \\
\text { - Ketebalan : } 0,37 \\
\text { mm } \pm 0,17 \\
\text { - Daya lipat : > } 200 \mathrm{kali}\end{array}$ & $\begin{array}{l}\text { - Diameter : } \\
\text { Sesuai dengan } \\
\text { cetakan } \\
\text { sediaan yaitu } \\
\text { pada cawan }\end{array}$ \\
\hline F2 & 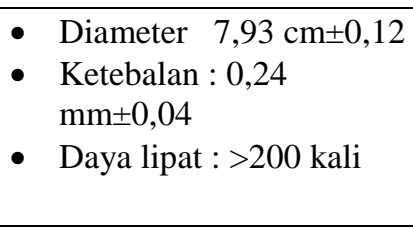 & $\begin{array}{l}\text { petri diameter } \\
\pm 9 \mathrm{~cm} \\
\text { Ketebalan : } \\
\text { 0,4-0,7 mm, } \\
\text { dengan standar } \\
\text { deviasi yang }\end{array}$ \\
\hline F3 & 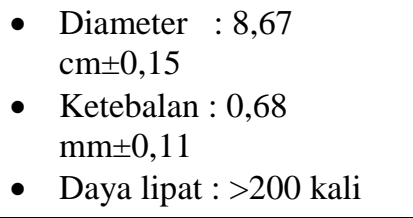 & $\begin{array}{l}\text { rendah }{ }^{17} \text {. } \\
\text { Daya lipat: } \\
>200 \text { kali }^{17} \text {. }\end{array}$ \\
\hline F4 & $\begin{array}{l}\text { Diameter : } 8,17 \\
\mathrm{~cm} \pm 0,29 \\
\text { - Ketebalan : } 0,17 \\
\text { mm } \pm 0,01 \\
\text { - } \text { Daya lipat : } 5 \text { kali }\end{array}$ & \\
\hline F5 & $\begin{array}{ll} & \text { Diameter : } 8,37 \\
& \mathrm{~cm} \pm 0,23 \\
\text { - } & \text { Ketebalan : } 0,35 \\
& \text { mm } \pm 0,34 \\
\text { - } & \text { Daya lipat : >200 kali }\end{array}$ & \\
\hline
\end{tabular}

Pada uji karakteristik daya tahan lipatan yang dilakukan dengan melipat sediaan pada tempat yang sama didapatkan hasil yaitu formula 1, 2, 3, dan 5 memilik daya tahan lipatan hingga $>200$ kali sehingga telah mencapai spesifikasi, sedangkan pada formula 4 dimana sediaan memiliki ketebalan yang sangat tipis dan terlalu elastis sehingga tidak memenuhi spesifikasi yaitu daya tahan lipatan hanya 5 kali. Hal tersebut dapat diakibatkan karena karena formulasi sediaan hanya mengandung PVP. PVP dapat berfungsi sebagai peningkat elastisitas pada polimer lainnya, namun pada formula 4 PVP digunakan 
tunggal sehingga sediaan menjadi terlalu elastis dan mudah robek ${ }^{16}$.

\section{Rasio Swelling}

Hasil pembuatan hidrogel formula 1, 2, 3, 4 dan 5 diuji kesesuaian rasio swelling sediaan dan dibandingkan dengan spesifikasi, hasil uji evaluasi rasio swelling sediaan ditunjukkan pada gambar 1

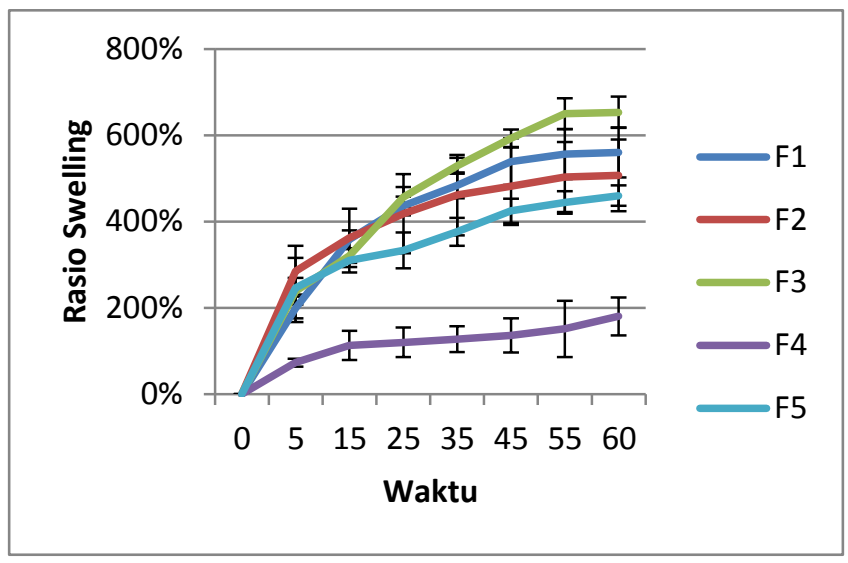

Gambar 1. Hasil Uji Rasio Swelling

Hasil yang didapatkan yaitu formula 1,2, dan 3 telah memenuhi spesifikasi rasio swelling yaitu mencapai $500 \%$ dari berat awalnya, sedangkan formula 4 , dan formula 5 belum memenuhi spesifikasi dimana nilai ratarata rasio swelling tidak mencapai $500 \%$.

Uji rasio swelling pada sediaan dilakukan bertujuan untuk mengetahui kemampuan dari hidrogel dalam menyerap cairan, dimana kemampuan tersebut dapat menentukan kemampuan hidrogel dalam menyerap eksudat luka. Rasio swelling meningkat sebanding dengan ketebalan dari sediaan, dimana pada formula 1 hingga 3, formula 3 mempunyai ketebalan yang paling besar diikuti dengan formula 1, kemudian formula 2 . Hal dapat diakibatkan karena tebal sediaan yang paling tebal diantara setiap formula sehingga kemampuan sediaan dalam menyerap air lebih tinggi.

Formula 4, dan 5 yang merupakan hidrogel dengan formula tanpa kombinasi yaitu formula 4 dengan PVP, dan formula 5 dengan galaktomanan mempunyai nilai rasio swelling yang paling rendah diantara semua formula. Pada formula 4 dengan komposisi PVP mempunyai rasio swelling yang paling rendah dikarenakan PVP mempunyai kemampuan swelling yang rendah ${ }^{10}$. Sedangkan pada formula 5 dengan komposisi galaktomanan mempunyai rasio swelling yang rendah yaitu kurang dari $500 \%$ sehingga tidak memenuhi spesifikasi ${ }^{18}$. Rasio swelling dengan nilai tertinggi didapatkan pada formula 3 dengan konsentrasi PVP yang paling tinggi yaitu $2 \%$, hal tersebut dapat menunjukkan bahwa kombinasi dari kedua polimer dapat meningkatkan kemampuan menyerap dari sediaan dibandingkan dengan penggunaan polimer tunggal.

\section{Fraksi Gel}

Hasil pembuatan hidrogel formula 1, 2, 3, 4 dan 5 dilakukan uji evaluasi fraksi gel,hasil perhitungan pada uji fraksi gel ditunjukkan pada tabel 5.

Tabel 5. Hasil Uji Fraksi Gel

\begin{tabular}{ccc}
\hline Formula & Rata-Rata Fraksi Gel & SD \\
\hline F1 & $9 \%$ & 0,035 \\
\hline F2 & $14 \%$ & 0,051 \\
\hline F3 & $3 \%$ & 0,004 \\
\hline F4 & $3 \%$ & 0,015 \\
\hline F5 & $13 \%$ & 0,064 \\
\hline
\end{tabular}

Hasil yang didapatkan yaitu fraksi gel terbesar pada formula 2 dan 5, dengan nilai sebesar 14\%, dan $13 \%$ secara berurutan. sedangkan fraksi gel terkecil ada pada formua 1, 3, dan 4, dimana nilai yang didapatkan secara berurutan sebesar $9 \%, 3 \%$, dan $3 \%$.

Hasil pengujian fraksi gel dapat dilihat pada tabel 5. Banyaknya fraksi yang tidak terlarut dalam sediaan menunjukkan ikatan silang yang terbentuk dari hidrogel ${ }^{19}$. Berdsarkan hasil pada tabel 5 nilai fraksi gel tertinggi terdapat pada formula 2 yaitu sebesar $14 \%$ dimana merupakan kombinasi galaktomanan dan PVP 1:1, sedangkan pada formula 3 yang mempunyai nilai rasio swelling tertinggi memiliki nilai fraksi gel yang rendah dikarenakan semakin tinggi rasio swelling maka akan semakin mudah hidrogel dalam menyerap air, dan semakin banyak rongga yang terdapat dalam hidrogel, sehingga jaringan terikat silang yang terbentuk dalam hidrogel juga akan semakin kecil $^{20}$.

Formula 4 dengan koponen PVP tunggal tanpa kombinasi juga memiliki nilai fraksi gel yang rendah yaitu sebesar 3\%, dikarenakan sediaan yang terlalu tipis dan mudah robek, sehingga ketika dilakukan perendaman selama 24 jam banyak komponen yang hilang larut dalam air. Sedangkan pada formula 5 dengan komponen tunggal galaktomanan mempunyai nilai fraksi gel yang cukup tinggi yaitu sebesar 13\%, namun tidak lebih besar dari formula 2 yang menggunakan kombinasi polimer. Nilai fraksi gel pada formula 2 yang mencapai 14\% dan dengan nilai rasio swelling 507\% merupakan kombinasi yang sesuai karena memiliki nilai fraksi gel baik dengan nilai rasio swelling yang baik pula. Pada penelitian Kartika et al., (2015) dihasilkan kombinasi hidrogel dengan formula yang optimal dengan konsentrasi PVP yang digunakan adalah sebesar $1 \%$, dan jika digunakan lebih dari $1 \%$ sediaan hidrogel tidak dapat terbentuk dengan baik ${ }^{21}$. 


\section{Daftar Pustaka}

1. Velnar, T., Bailey, T., dan Smrkoli, V., 2009, The Wound Healing Process: An Overview of the Cellular and Molecular Mechanisms, J. Int. Med. Res., 37 (5): 1528-1542.

2. Uzun, Muhammet. 2018. A Review of Wound Management Material. Journal of Textile Engineering and Fashion Technology 2018, 4(2):00121. Departement of Textile Engineering, faculty of Technology Marmara Universuty, Turkey.

3. Singh, Shailesh Kumar, Dhyani, Ardana dan Divya Juyal. 2017. Hydrogel : Preparation, Characterization anda Applications. The pharma Innovation Journal 2017;6(6):25-32.

4. Gadri, et al. 2014. Formulasi Pembalut Luka Hidrogel Berbasis I-Karagenan dengan Metode Freezing and Thawing Cycle. Prosiding SnaPP2014 Sains, Teknologi, dan Kesehatan.

5. Prajapati, V.D. 2013. Girish K. Jani a, Naresh G. Moradiyaa, Narayan P. Randeriaa, Bhanu J. Nagarb, Nikhil N. Naikwadia, Bhavesh C. Variyac International Journal of Biological Macromolecules: Galactomannan: A versatile biodegradable seed polysaccharide, 60 (2013) 83-92.

6. Tripathy, et al. 2013. Guar Gum : Present Status and Applications (Review Artikel). Journal of Pharmaceutical and Scientific Innovation, JPSI 2 (4), Jul-Aug 2013, 24-28.

7. Pasha, Mazhar, dan Swamy Ngn. 2008. Derivatization of Guar to Sodium Carboxy Methyl Hydroxy Propyl Derivative; Characterization and Evaluation. Pak. J. Pharm. Sci., Vo.21, No.1, January 2008, pp.40-44.

8. Biswas, G.P., Maje, S.B., dan Animikh Roy. 2016. Combination of Syntetic and Natural Polymers in Hydrogel : An Impact on Drug Permeation. Journal of Applied Pharmaceutical Science Vol.6 (11), pp. 158-164, November 2016.

9. Hamzah, Nursalam. 2017. Teknik Sintesis Povidon. JK FIK UINAM vol.5 No.3 2017. Universitas Islam Negeri Alauddin.

10. Roy, Niladri, dan Nabanita Saha. 2012. PVP-Based Hydrogels: Synthesis, Properties and Applications. Centre of Polymer Systems, Tomas Bata University in Zlin, Nam T.G. Masaryka 5555, 76001, Zlin, Czech Republic.

11. Gadri, et al. 2014. Formulasi Pembalut Luka Hidrogel
Berbasis I-Karagenan dengan Metode Freezing and Thawing Cycle. Prosiding SnaPP2014 Sains, Teknologi, dan Kesehatan.

12. Rao, N. G. R. dan K. Patel. 2013. Formulation and evaluation of ropinirole buccal patches using different mucoadhesive polymers. J. Pharm Scl. 3(1): 32-39.

13. Ali, S. M. dan Yosipovitch, G. Skin pH: From Basic Science to Basic Skin Care. Acta Derm Venerol, 2013, 93: 261-267.

14. Prabhakara, P., Koland, M., Vijaynaraya, K., Haarris, NM., Shankar, G., Mohd, G A., Narayana, C.R., Satyanarayana, D., 2010, Preparationand Evaluation of Transdermal Patches of Papaverin Hydrochloride, J.Res.Pharm ., 1:259-266

15. Fitriyah, Hissi. Formulasi Patch Natrium Dikofenak Berbasis Polimer Hidroksipropil Metilselulosa (HPMC) Sebagai Sediaan Lokal Penanganan Inflamasi Pada Penyakit Periodontal. Skripsi. Tidak Diterbitkan. Universitas Islam Negeri yarif Hidayatullah. Jakarta. 2013.

16. Jadhav, Jaydatt K. Sreenivas, 2012. Formulation and Invitro Evaluation of Indomethacin Transdermal Patches Using Polymers PVP and Etyl Cellulose. International journal of pharmacy and pharmaceutical sciences, vol. 4(1):1-7

17. Chatterjee, A., Mohan, S., Himanshu, M., Varshney, M., Jaimini, M., Chauhan, B., Formulation and InVitro Characterization of Zaltoprofen Transdermal Patch Using Different Polymers, International Journal of Pharmaceutical Sciences Review and Research, 2014, 27(1): 277-282.

18. Siqueira, Nataly M, et al. 2015. Gelatin and Galactomannan-Based Scaffolds: Characterization and Potential for Tissue Engineering Applications. Journal of Carbohydrate Polymers 133 (2015) 8-18.

19. Abidin, A.Z., dkk. 2012. Sintesis dan Karakterisasi Polimer Superabsorben dari Akrilamida. Jurnal Teknik Kimia Indonesia, 11(2), hlm. 87-93.

20. Nurrahmi, Febi., Siregar, Yusni Ikhwan., dan Dina Fransiska. 2016. Production Of Basic Material Carrageenan Hydrogel Using Polymer Based Polyvinyl Alcohol (PVA). Marine Science Department, Faculty of Fisheries and Marine Science, University of Riau, Pekanbaru, Riau Province.

21. Kartika, Rikka, et al. 2015. Formulasi Basis Sediaan Pembalut Luka Hidrogel dengan Teknik Beku Leleh Menggunakan Polimer Kappa Karangenan. Prosiding Penelitian. 